\title{
Effect of Environmental Parameters on the Reproduction of the White Mullet (Mugil curema, Valenciennes, 1836) in the Saloum Delta (Senegal)
}

\author{
Waly Ndiaye (Corresponding author) \\ Institut Universitaire de Pêche et d'Aquaculture (IUPA), Cheikh Anta Diop University, Dakar, \\ UCAD II bâtiment pédagogique/Rez de chaussée BP 5005 Dakar-Fann, Sénégal \\ Tel: (+221) 775601547; E-mail: lywa01@yahoo.fr

\begin{abstract}
Khady Ndiaye
Institut Universitaire de Pêche et d'Aquaculture (IUPA), Cheikh Anta Diop University, Dakar, UCAD II bâtiment pédagogique/Rez de chaussée BP 5005 Dakar-Fann, Sénégal
\end{abstract}

\section{Alassane Sarr}

Institut Universitaire de Pêche et d'Aquaculture (IUPA), Cheikh Anta Diop University, Dakar, UCAD II bâtiment pédagogique/Rez de chaussée BP 5005 Dakar-Fann, Sénégal

\section{Patrick Diédhiou}

Institut Universitaire de Pêche et d'Aquaculture (IUPA), Cheikh Anta Diop University, Dakar, UCAD II bâtiment pédagogique/Rez de chaussée BP 5005 Dakar-Fann, Sénégal

Received: August 8, $2021 \quad$ Accepted: September 9, $2021 \quad$ Published: February 8, 2022

doi:10.5296/jbls.v13i1.18914ＵRL: https://doi.org/10.5296/jbls.v13i1.18914

\begin{abstract}
Mugil curema, known as white mullet, was one of the fish species encountered in the fisheries landings of the Saloum Delta. In this study, the morphometric parameters and the reproductive biology of this species were studied as well as the influence of environmental parameters on its reproduction. Experimental fisheries were carried out monthly in the Saloum Delta. The fish were caught using surface drift nets. The captured individuals were measured and weighed. The gonads were collected to determine the sex and the stages of
\end{abstract}


sexual maturity. Out of a total of 406 individuals sampled in the Saloum Delta, 306 females and 100 males were identified, no individuals of undetermined sex were obtained. The sex ratio was globally in favor of females. Individuals in this study ranged in size from 102 to $385 \mathrm{~mm}$ and weight from 34.9 to $395 \mathrm{~g}$. The allometric coefficient $\mathrm{b}$ was equal to 2.40 and indicated a negative allometry. The exploitation of the monthly IGS results indicated that reproduction was in April, May and June. The size at first sexual maturity indicated that the males matured at a size of $220 \mathrm{~mm}$, lower than that of the females $226 \mathrm{~mm}$.

Keywords: Mugil curema, reproduction, environmental parameters, Saloum Delta

\section{Introduction}

Fisheries and aquaculture remain a key resource for hundreds of millions of people around the world in terms of food, nutrition, income and livelihoods. In 2014, global fish supply reached a record $20 \mathrm{~kg}$ per capita, driven by strong growth in aquaculture, which now provides half of the fish for human consumption, and a slight improvement in the condition of some fish stocks due to better fisheries management. Fish continues to be one of the most traded food commodities in the world, with more than half of the export value coming from developing countries. Recent reports by high-level experts, international organizations, industry and civil society representatives highlight the significant contribution that oceans and inland waters can, and especially will in the future, make to the food security and nutrition of a global population expected to reach 9.7 billion people by 2050 (FAO, 2016)

In Senegal, one of the world's most fish-rich regions, the fishing sector is growing steadily and plays a vital role in the national economy. This country has geographical and climatological advantages that give its coastline a reputation as a very productive area of the West African coast. The Sine-Saloum estuary drains one of the most populated parts of Senegal with more than one-sixth of the population (1.5 million inhabitants) for an area that represents only $1.2 \%$ of the national territory. Fisheries resources are of paramount importance to these populations as they are the main source of animal protein and income, following the decline in agriculture (Kébé, 1994). The fishing pressure on the stocks as well as the change in environmental parameters have led to the reduction of the productivity of the fish stocks in this part of Senegal.

The group of small pelagic fish is made up of all the small fish that spend most, if not almost all, of their adult phase on the surface or in open water. These species are totally free from the bottom and are independent of the nature of the substrate (Laloë and Samba, 1990). The influence of the environment on their biology and fluctuations in their availability and abundance has been demonstrated in many fisheries around the world (Belvèze, 1984; Cury and Fontana, 1988; Fréon, 1988; Binet, 1995; Csirke, 1995; Pauly, 1997).

Mugil curema, belonging to the mugilidae family, occupies a significant place in the landings. It is of great importance for the populations. However, in the West African sub-region, very little scientific data exists on the biology of this species.

This study was carried out in order to participate in the search for good management of fishery resources in general and white mullet in particular in the Saloum Delta. The data used 


\section{$\triangle$ Macrothink}

in this study come from the experimental fishing campaigns carried out in the area.

The aim of this study was to contribute to the improvement of the management of the $M$. curema fishery in the Saloum Delta by evaluating the reproductive parameters and the environmental impact in order to ensure a sustainable use of this resource for the benefit of the coastal populations.

\section{Material and Methods}

\subsection{Study Area}

The Saloum Delta area is located between $13^{\circ} 35^{\prime}$ and $14^{\circ} 10^{\prime} \mathrm{N}$ latitude and $16^{\circ} 13^{\prime}$ and $16^{\circ} 50^{\prime} \mathrm{W}$ longitude. It is bordered to the north by the department of Mbour, to the south by the Republic of Gambia, to the east by the Kaolack region and to the west by the Atlantic Ocean (Figure 1). The Saloum Delta is one of the most amazing and beautiful natural regions of Senegal. Located at the confluence of the Sine and Saloum rivers, it covers some 334,000 ha which are divided into nine classified forests, two marine protected areas, two community nature reserves, not to mention the 76,000 ha of the Saloum Delta Natural Park; all classified as a World Biosphere Reserve by UNESCO and a wetland of international importance. The Saloum Delta is made up of three main arms: the Saloum in the north (110 km long), the Bandiala in the south $(18 \mathrm{~km})$ and the Diombos in between $(30 \mathrm{~km})$. These rivers are surrounded by a very dense set of salt water channels, called bolongs. The latter divide the land of the Delta to create a maze of more than 200 islands covered with a lush vegetation of mangroves, mangroves, baobabs and cheese trees. The research was specially done in the Saloum River, the richest in terms of specific diversity but the most frequented by fishermen.

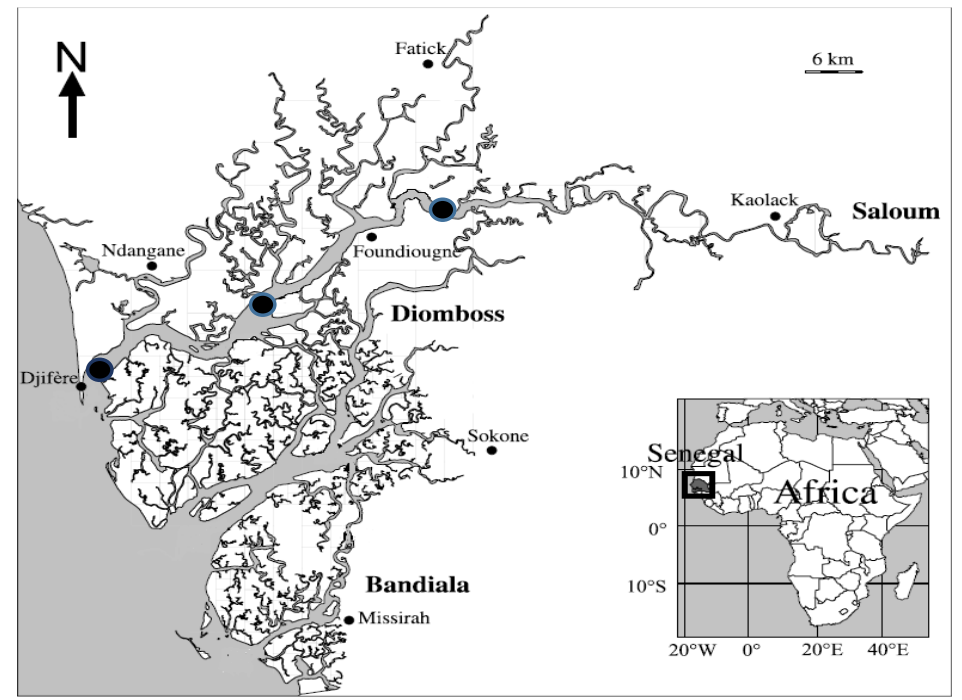

Figure 1. Map of study area, the Saloum Delta of Senegal and plot of the fishing operations

\section{$(9$}

\subsection{Sampling Strategy}

In order to study the reproductive biology of Mugil curema, experimental fisheries were carried out monthly in the MPAs of Sangomar and Gandoul (Saloum Delta). These fisheries 
were carried out using surface drift gillnets. Sampling was carried out at several sites divided into 3 levels (mouth, middle of the river and downstream), identified by GPS coordinates. All sites were fished during the day with the same time of setting of the fishing gear. Species caught were sorted and M. curema isolated for this study.

\subsection{Morphometric Relationships}

\subsubsection{Length-weight Relationship (LWR)}

The relationship between the total length of fish and their weight is generally of the power type. It is represented by the relationship:

$$
\mathrm{TW}=\mathrm{a} \times \mathrm{TL}^{\mathrm{b}}
$$

Where $\mathrm{TW}=$ total weight $(\mathrm{g}) ; \mathrm{TL}=$ total length $(\mathrm{mm}), \mathrm{a}=$ slope and $\mathrm{b}=$ allometry coefficient. The coefficient $b$ varies between 2 and 4 , but is often close to 3 . It expresses the relative shape of the body of a fish. When it is equal to 3 , the growth is said to be isometric. When it is different from 3, the growth is allometric. A coefficient $b$ greater than 3 indicates better growth in weight than in length and vice versa.

\subsubsection{Condition Coefficient}

The condition factor (K), allows to determine the physiological state of a fish, including its reproductive capacity as well as the influence of the living environment on the species. The condition factor indicates the conditions of the fish and water, and their interactions. Thus, the heavier a fish is for a given length, the higher its condition coefficient. It is defined by the ratio between the weight and the size of the fish.

$$
\mathrm{TW}=\frac{\mathrm{TW}}{\mathrm{TL}} \times 10^{5}
$$

Where PT $=$ total weight $(\mathrm{g})$ and $\mathrm{LT}=$ total length $(\mathrm{mm})$

\subsection{Biological Parameters}

\subsubsection{Sex Ratio}

The sex ratio is defined as the proportion of males or females in the total population and gives an idea of the sex balance in the population. The sex ratio generally reflects the rate of femaleness of the population.

$$
\mathrm{SR}=\frac{\mathrm{Nf}}{\mathrm{Nf}+\mathrm{Nm}} \times 100 \quad \text { or } \quad \mathrm{SR}=\frac{\mathrm{Nm}}{\mathrm{Nf}+\mathrm{Nm}} \times 100
$$

Where $\mathrm{Nf}=$ number of females and $\mathrm{Nm}=$ number of males

\subsubsection{Gonado-somatic Index (GSI)}

The gonado-somatic index indicates the stage of development of the gonads and determines the spawning periods during the sexual cycle of a species. 


$$
\mathrm{GSI}=\frac{\mathrm{Wg}}{\mathrm{TW}} \times 100
$$

Where $\mathrm{Wg}=$ weight of gonads $(\mathrm{g})$ and $\mathrm{TW}=$ total weight of fish $(\mathrm{g})$

\subsubsection{Size at First Sexual Maturity (L50)}

Among the essential parameters to know about sexuality, the size of first sexual maturity is one of the most important. It is the one that will inform us on the fraction of the stock that is able to ensure the renewal of the species and consequently inform us on the minimum legal size of the fish that can be caught. The exact definition of this first size varies according to the authors.

However, in the majority of studies, the size of first sexual maturity is defined as the size for which $50 \%$ of the individuals are mature.

$$
\% \mathrm{M}=\frac{100}{1+\mathrm{e}-\mathrm{a}(\mathrm{L}-\mathrm{L} 50)}
$$

Where $\% \mathrm{M}$ is the percentage of mature individuals per size class; $\mathrm{L}$ is the central value of the total length size classes, a and L50 are model constants.

\section{Results}

\subsection{Environmental Parameters}

The environmental parameters were summarized in Table 1.

Monthly measurements of $\mathrm{pH}$ values showed that they varied between 7.67 (June) and 8.26 (February). The average $\mathrm{pH}$ value (8.02) indicated that the waters of the Saloum Delta were basic throughout the year with a $\mathrm{pH}$ higher than 8 except for the months of June, July and August when the $\mathrm{pH}$ was equal to $7.67 ; 7.90$ and 7.98 respectively.

Water temperatures ranged from 21.34 to $30.24{ }^{\circ} \mathrm{C}$ with an average of $26.01{ }^{\circ} \mathrm{C}$. The water temperature was highest in August $\left(30.24{ }^{\circ} \mathrm{C}\right)$ and lowest in January $\left(21.34{ }^{\circ} \mathrm{C}\right)$.

Conductivity values recorded monthly in the Saloum Delta ranged from 52.71 (September) to 61.69 (April) with an average value of 58.17. Conductivity values measured in April (61.69) and May (61.38) were much higher than in the other months of the year. However, they were lower in September (52.71) and October (52.85).

In the Saloum Delta, an analysis of salinity values had found a variation in salinity between 34.34\% (March) and 41.69\% (June). The average marine salinity in this estuary was $38.44 \%$. The maximum values of salinity were noted in the months of April, May and June with 40.37 ; 40.41 and $41.69 \%$ respectively.

The monthly evolution of the dissolved oxygen content had known a slight variation during the year. It was around the value of 3 from March to November, therefore in the warm season. It gravitated around 4 from December to February, in the cold season and was maximum in January (4.53), minimum in September (3.18). 


\section{Macrothink}

Table 1. Environmental parameters

\begin{tabular}{lccccc}
\hline Months & $\mathbf{p H}$ & Temp $\left({ }^{\circ} \mathbf{C}\right)$ & Cond & Sal $(\mathbf{p p t})$ & DO $\left(\mathbf{m g ~ \mathbf { ~ I } ^ { - 1 } )}\right.$ \\
\hline January & 8.18 & 21.34 & 59.68 & 39.76 & 4.53 \\
February & 8.26 & 22.56 & 59.13 & 39.59 & 4.07 \\
March & 8.04 & 23.47 & 58.82 & 34.34 & 3.95 \\
April & 8.03 & 24.33 & 61.69 & 40.37 & 3.80 \\
May & 8.07 & 25.21 & 61.38 & 40.41 & 3.51 \\
June & 7.67 & 28.35 & 56.92 & 41.69 & 3.53 \\
July & 7.90 & 29.39 & 60.51 & 39.72 & 3.42 \\
August & 7.98 & 30.24 & 58.34 & 38.92 & 3.43 \\
September & 8.01 & 29.59 & 52.71 & 34.51 & 3.18 \\
October & 8.11 & 30.17 & 52.85 & 34.70 & 3.63 \\
November & 8.05 & 26.13 & 56.96 & 37.80 & 3.89 \\
December & 8.05 & 21.45 & 59.05 & 39.54 & 4.23 \\
Average & 8.02 & 26.01 & 58.17 & 38.44 & 3.76 \\
\hline
\end{tabular}

Temp $=$ temperature Cond $=$ conductivity $;$ Sal = salinity $; \mathrm{DO}=$ dissolved oxygen

\subsection{Morphometric Relationships}

\subsubsection{Length-frequency Distribution}

During the sampling, a total of 406 fish were measured in the area. Length-frequency distribution was given in Figure 2. The size structure of fish collected in Saloum Delta ranged from 102 to $385 \mathrm{~mm}$. The distribution of 406 catches in length according to classes of maximum length of species showed that most of the half of the total length was made of species reaching 205-265 mm. No significant difference (ANOVA, $p>0.05$ ) was shown for fish length.

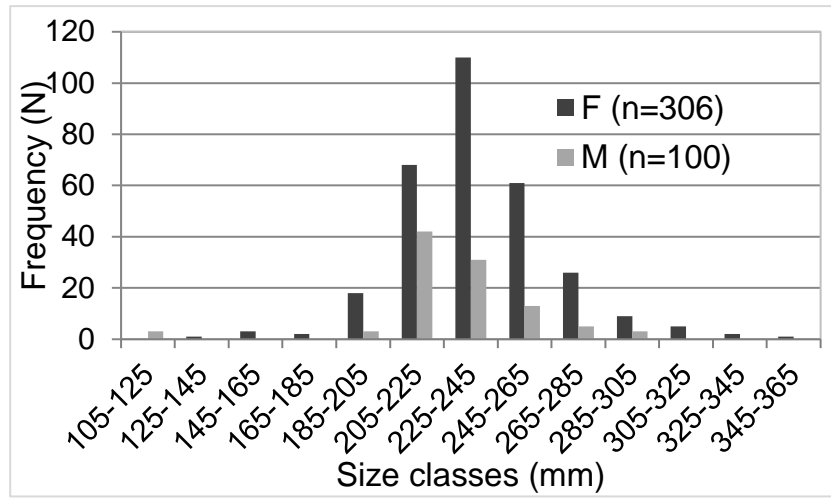

Figure 2. Length frequency distribution of Mugil curema in the Saloum Delta of Senegal

\subsubsection{Length-weight Relationship}

The relationship between total weight and total length for all $M$. curema individuals sampled in the Saloum was shown in Figure 3. Delta was represented in this study by a power function: $\mathrm{TW}=10^{-3} \times \mathrm{TL}^{2.40}$. The scatterplot from the relationship between the two variables studied for all sexes combined was poorly dispersed for all sizes. The value of the allometry coefficient 
(b) was equal to 2.40 , which reflected a negative allometric growth. The high value of the coefficient of determination $\left(\mathrm{r}^{2}=0.92\right)$, close to 1 , indicated a strong correlation between the two variables studied.

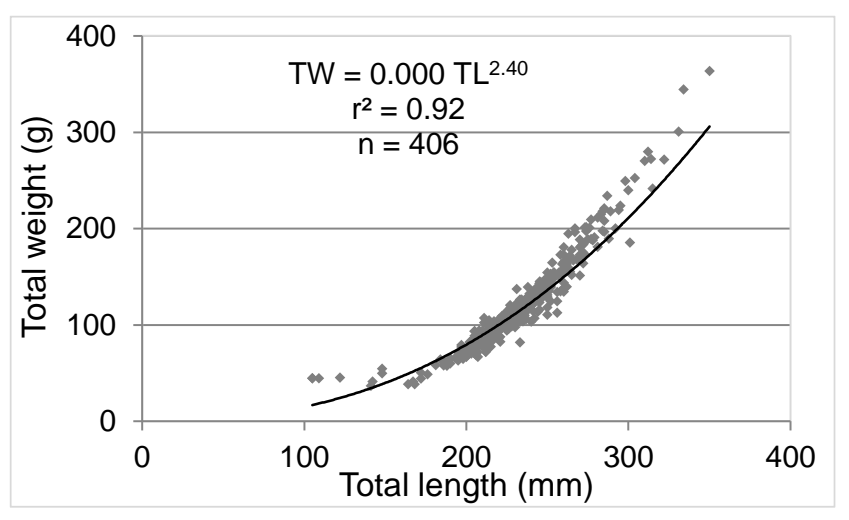

Figure 3. Length-weight relationship of Mugil curema in the Saloum Delta of Senegal

\subsubsection{Condition Factor}

The monthly values of the condition factor varied between 0.93 and 1.1 . The maximum value was observed in June (1.1) and the lowest were recorded in April (0.78) and May (0.80). This indicated that in April and May, M. curema used its energy reserves to manufacture muscle tissue (Figure 4) There was no significant difference between months (ANOVA, $p>0.05$ ).

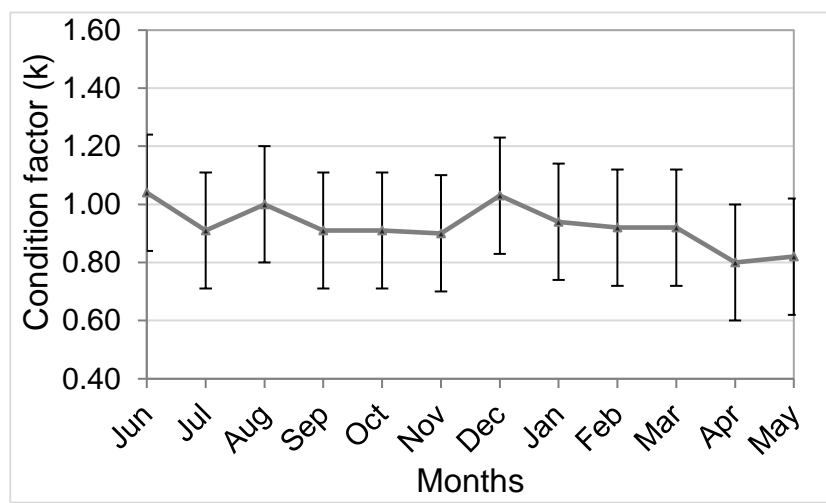

Figure 4. Condition factor variation of Mugil curema in the Saloum Delta of Senegal

\subsection{Biological Parameters}

\subsubsection{Sex Ratio}

From a set of 406 individuals of M. curema sampled in the Saloum Delta from January 2010 to December 2010, 306 females and 100 males were identified, no individuals of undetermined sex were obtained. The sex ratio was globally unbalanced in favor of females which represented $75 \%$ of the total number, while males represented $25 \%$ (ANOVA, $p<0.05$ ) (Figure 5). The predominance of females in the Saloum Delta occurred in almost all the size classes except for 105-125 mm, 


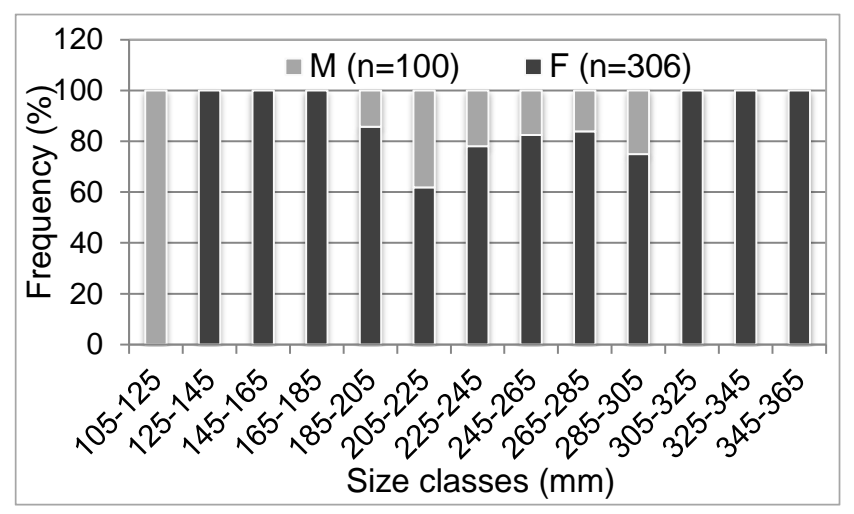

Figure 5. Sex ratio of Mugil curema in the Saloum Delta of Senegal

\subsubsection{Gonado-somatic Index (GSI)}

The monitoring of the monthly evolution of the GSI had shown globally two phases. The first phase from July ( 0.2 for males and 0.35 for females) to March ( 0.19 for males and 0.25 for females) was characterized by relatively low values of GSI and reflected the fact that all the fish were at the beginning of maturation and were preparing to spawn. The second phase (April-May-June) was characterized by high GSI values. These three months were significantly different from the others (ANOVA, $p<0.05$ ). In May the GSI was at its maximum ( 0.60 for males, 1.19 for females) and for a majority of individuals spawning could start (Figure 6).

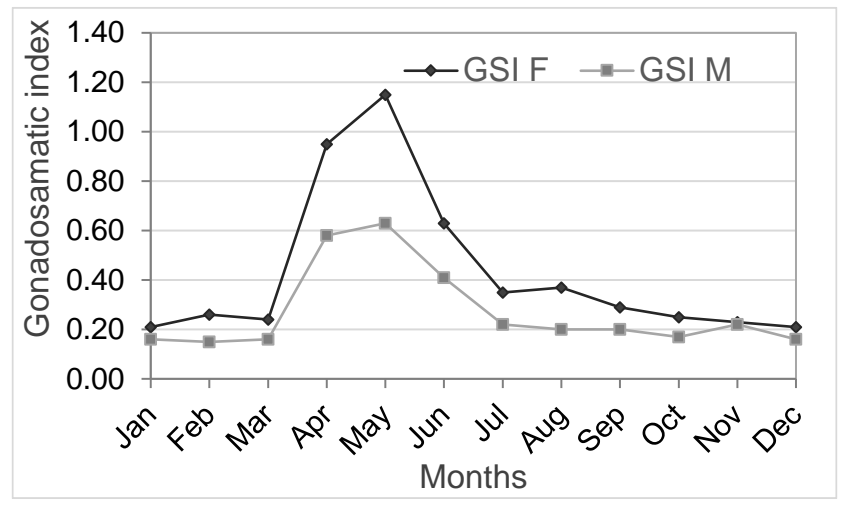

Figure 6. Gonadosomatic index of Mugil curema in the Saloum Delta of Senegal

\subsubsection{Size at First Sexual Maturity (L50)}

The size at first sexual maturity is by convention the size at which $50 \%$ of the individuals are mature. Curve analysis had shown that the size at first sexual maturity in $M$. curema females was equal to $226 \mathrm{~mm}$ (TL) and that of males was $220 \mathrm{~mm}$ (TL). Males reached sexual maturity at a smaller size than females (Figure 7). The difference between the maturity sizes of the two sexes was not too significant (ANOVA, $\mathrm{p}>0.05$ ). 


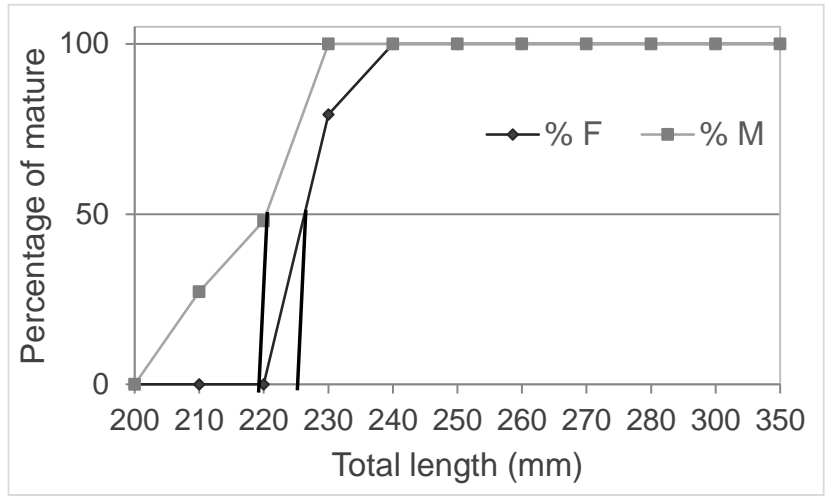

Figure 7. Size at first sexual maturity of Mugil curema in the Saloum Delta of Senegal ç

\section{Discussion}

\subsection{Environmental Parameters}

Temperature, dissolved oxygen, salinity and $\mathrm{pH}$ were very important water quality parameters related to the life of aquatic organisms (Pal et al. 2014). Salinity also affected chemical conditions within the estuary, particularly levels of dissolved oxygen in the water. The amount of oxygen that could dissolve in water, or solubility, decreased as salinity increased. During the months of August, September and October, which corresponded to the rainy season, salinity and conductivity were relatively low. These low values were due to the dilution of salt water by rainwater and runoff. During the months of April and May, which corresponded to the breeding period of the white mullet, a beginning of temperature increase was observed. The highest values of conductivity and salinity were also noted in this period. These parameters had an influence on the reproduction of white mullet in the Saloum Delta. The results of this study corroborated those of Albaret and Legendre (1985) who had shown that $M$. curema was only found in significant quantities in the sectors where the salinity class was the highest. These authors also found that the proportion of mature females increased considerably with salinity and they preferred the area with higher salinity for reproduction. Albaret and Legendre (1985) also showed that the highest catches of M. curema were taken in waters with low oxygen concentration (less than $2 \mathrm{ppm}$ ). This may be a particular adaptation of this species to reduce the strong competition for food with competing species.

\subsection{Length-weight Relationship}

The exponent $\mathrm{b}$ of the length-weight relationship of $M$. curema was significantly different from 3.0. That was an indication that white mullet from the Saloum Delta exhibited negative allometric growth. A similar observation of allometric growth was made by King (1996) for $M$. curema on the Nigerian coast. The results of research had a negative allometric growth pattern with a b-value of 2.40 and a coefficient of determination $\left(\mathrm{r}^{2}\right)$ of 0.92 which indicates that $92 \%$ of weight growth was influenced by growth length (Seiyaboh et al. 2016). The 
lower $b$ values found in the present study for this species in comparison with the available information may be due to other uncontrolled factors such as season or extreme environments.

\subsection{Condition Factor}

Condition factor measures the condition of fish, its nutritional state or physiological well-being. It is also a measure of the 'fitness' of the fish population as it is used to as rough estimate of the state of fish, whether healthy or unhealthy, starved or well-fed, spawning or spent (Busacker et. al. 1990). Busacker et al. (1990) reported that any condition factor, $\mathrm{k} \geq$ 0.5 implies that the fish is in good condition (or high nutritional state). Therefore, $0.8 \pm 0.01$ $-1.1 \pm 0.09$ condition factors recorded showed that the fish were in good condition and high nutritional state in the habitat during this study.

\subsection{Sex Ratio}

Of a total of 406 individuals sampled in this study, 306 were females and 100 were males. This corresponded to a sex ratio largely favorable to females (75.36\%). This observation was in agreement with the results of several authors. Indeed, Diaby et al. (2012) pointed out that, in mules, females often slightly outnumbered males. Salvador (2017) also claimed to have identified 375 females to 110 males in the coastal lagoon of Barra de Navidad, Jalisco, Mexico. A significant predominance of $M$. curema females was also noted in two regions of southeastern Brazil (the Cananéia-Iguape coastal system and the Santos estuary) by Fernandez and Dias (2013). This predominance of one sex was a relatively common phenomenon in many teleost fish species (Djadji et al. 2013). According to Sylla et al. (2009), several factors such as foraging movement and sex-specific mortality rate also influenced the sex ratio in fishes. In addition, Chikou (2006) noted that fish could exhibit gregarious behavior that was strongly related to sex. Mugilidae were known to be gregarious fishes in which there was segregation by year class and sex during their movement (Vall, 2004). Thus, the banks most accessible to fishing gear had a direct influence on the sex ratio. Fishing at the same locations tended to take individuals of one sex more than another. (Diaby et al. 2012).

\subsection{Gonado-somatic Index}

The reproductive timing and spawning seasons of $M$. curema showed great variation in its geographic distribution. The times when white mullet chose to engage in reproductive activities varied among locations. This study determined a spawning period of April-May in the Saloum Delta. In Brazil, spawning occurred between November and January and in the Gulf of Mexico, from February to May (Castro et al. 2015). Many authors reported an extended spawning period for the species, usually with two spawning peaks throughout the year (Jacot, 1920; Anderson, 1957; Angell, 1973; Ibañez-Aguirre, 1993; Marin et al. 2003). M. curema was a multi-batch spawner with an extended spawning season from November to July. Gonadal development was annual and each female appeared to spawn at least twice a year. The extended spawning period could therefore be an indication of lack of population synchrony rather than extended spawning by a single individual. (Salomon et al. 2007). M. curema from the Cananeia-Iguape coastal system and Santos estuary had shown the onset of 
gonadal maturation in October, which extended into April, with two annual spawning events (April and November) (Fernandez and Dias, 2013). The study of the reproduction of $M$. curema in a tropical bay in southeastern Brazil showed that spawning took place between August and January. (Albieri et al. 2010). According to Albaret (2003), reproduction of this species was possible in the Bamboung bolon, but the low proportions of individuals in sexual activity indicated that it probably took place, mostly outside, i.e. in other areas of the Sine Saloum and/or at sea. The end of the dry season was the period of maximum sexual activity for this species. In the lagoon of Grand-lahou (Ivory Coast); Diaby (2012) revealed that reproduction in $M$. curema was spread over the months of September and October. Solomon and Ramnarine (2007) had reported that $M$. curema in the southern Caribbean was a multi-batch spawner with an extended spawning season from November to July, with gonad development being annual and each female appearing to spawn at least twice a year. In Cuyulan Lagoon, M. curema exhibited a longer spawning season; the species spawned throughout the year with two maximum peaks: one in August and the other in January-February (Cabral-Solis et al. 2010). Results quite similar to those of this study were found by Ibañez-Aguire and Gallardo-Cabello (2004) who recorded a spawning period of $M$. curema between February and May, with a peak in April in a Mexican coastal lagoon. Finally, the spawning period of $M$. curema was very variable depending on the location and the authors. Thus, it appeared that the reproductive periodicity of white mullet varied according to its geographic distribution (Marin et al. 2003).

\subsection{Size at First Sexual Maturity}

The results of this study showed a size of first sexual maturity of $M$. curema equal to $22.6 \mathrm{~cm}$ in females and $22 \mathrm{~cm}$ in males. Males reached maturity at a relatively smaller size than females. Salvador (2017) had found first sexual maturity sizes close to those in this study; $21.7 \mathrm{~cm}$ in males and $24.5 \mathrm{~cm}$ in females. On the other hand Aguirre et al (2004) had found values of this size greater than those found in this study; $27.4 \mathrm{~cm}$ for males and $27.8 \mathrm{~cm}$ for females. According to Cabral-Solís et al. (2010) sexual maturation (L50) of males and females had been observed at an average size of $27 \mathrm{~cm}$ and $25.5 \mathrm{~cm}$ corresponding to five and four years, respectively in the lagoon of Cuyutlán, on the Pacific coast of Mexico. De Oliveira et al. (2011) found a total length at first sexual maturity equal to $264 \mathrm{~mm}$ for males and $240 \mathrm{~mm}$ for females in Northeast Brazil.

\section{Conclusion}

The present study showed that the sex ratio of $M$. curema was in favor of females. The reproduction of this species took place in the first half of the year with a more favorable period at the beginning of the warm season (April-May). The first sexual maturity was reached at a smaller size in males than in females. Through this study it was also found that the $M$. curema had preferences in those concerning environmental parameters. Its reproduction took place when the temperature, salinity and conductivity were high enough. Fishermen should avoid the capture of this species during the main spawning season, as well as the use of selective gears for. These measures should be developed to ensure a profitable and sustainable exploitation of the species. 


\section{References}

Aguirre, A., Ana Laura, I., \& Gallardo-Cabello, M. (2004). Reproduction de Mugil cephalus et de $M$. curema (Poissons: Mugilidae) d'un lagon côtier du golfe du Mexique. Bulletin des Sciences de la Mer, 75(1), 37-49.

Albaret, J. J. (2003). Caractérisation de l'état de référence des peuplements de poissons d'une aire protégée en zone de mangrove: le bolon de Bamboung (Sine Saloum, Sénégal). Dakar: IRD; OCEANIUM, 2003, 50 p.

Albaret, J. J., \& Legendre, M. (1985). Biologie et écologie des Mugilidae en lagune Ebrié (Côte d'Ivoire) Intérêt potentiel pour l'aquaculture lagunaire. Hydrobiologie Tropicale, 18(4), 281-303.

Albieri, R. J., Araujo, F. G., \& Uehara, W. (2010). Differences in reproductive strategies between two co-occurring mullets Mugil curema Valenciennes 1836 and Mugil liza Valenciennes 1836 (Mugilidae) in a tropical bay. Zoologie Tropicale, 23(1), 51-62.

Anderson, W. W. (1957). Développement précoce, frai, croissance et occurrence du mulet argenté (Mugil curema) le long de la côte sud-atlantique des États-Unis. Bulletin des pêches 57, 397-414.

Angell, C. (1973). Quelques aspects de la biologie de Lisa, Mugil curema Valenciennes, dans les eaux de hipersalinas du nororiente du Venezuela. La Salle de Ciencias Naturales, 51, 223-238.

Belvèze, H. (1984). Biologie et dynamique des populations de sardine (Sardina pilchardus Walbaum) peuplant les côtes atlantiques marocaines et propositions pour un aménagement des pêcheries. Thèse de Doctorat d'Etat de l'Université de Bretagne Occidentale, 532 pp.

Binet, D. (1995). Hypotheses accounting for the variability of sardinella abundance in the northern Gulf of Guinea. In F. X. Bard, \& K. A. Koranteg, (Eds.), Dynamique et usage des ressources en sardinelles de l'upwelling côtier du Ghana et de la Côte d'Ivoire (98-133 pp). Paris: ORSTOM.

Busacker, G. P., Adelman, I. R., \& Goolish, E. M. (1990). Growth. In C.B. Schreck, \& P. B. Moyle, (Eds.), Methods for fish biology (363 pp). American Fisheries Society, Bethesda, Maryland, USA- PCWA. https://doi.org/10.47886/9780913235584.ch11

Cabral-Solís, E. G., Gallardo-Cabello, M., Espino-Barr, E., \& Ibáñez, A. L. (2010). Reproduction de Mugil curema (Poissons: Mugilidae) à partir de la lagune de Cuyutlán, sur la côte pacifique du Mexique. Avances en Investigación Agropecuaria, 14(3), 19-32.

Castro, M. G., Pétoncle, J. P., Albieri, R. J., Mendonca, E., Villwock de Miranda, L., Fadré, M., \& Brick Peres, N. N. (2015). Mugil curema http://www.iucnredlist.org/details/full/190168/0.

Chikou, A. (2006). Etude de la démographie et de l'exploitation halieutique de six espèces de poissons-chats (Teleostein, siluriformes) dans le Delta de l'Ouémé au Bénin. Thèse Doct. 
Univ. Liège, Belgique 459 p.

Csirke, J. (1995). Fluctuations in abundance of small and mid-size pelagics. Science Marine, 59(3-4), 481-490.

Cury, P., \& Fontana, A. (1988). Compétition et stratégie démographiques comparées de deux espèces de sardinelles (Sardinella aurita et Sardinella maderensis) des côtes ouest africaines. Aquatic Living Resources, 1, 165-180. https://doi.org/10.1051/alr:1988018

De Oliveira, M. F., Dos Santos Costa, E. F., De Morais Freire, F. A., De Oliveira, J. E. L, \& Luchiari, A. C. (2011). «Quelques aspects de la biologie du mulet blanc, Mugil curema (Osteichthyes, Mugilidae), dans la région nord-est du Brésil». Pan-American Journal of Aquatic Sciences, 6(2), 138-147.

Diaby, M., N'da, K., \& Akadje, C. M. (2012). Distribution spatio-temporelle des poissons Mugilidae dans la lagune de Grand-lahou. International Journal of Biological and Chimical Sciences, 6(4), 1608-1623. https://doi.org/10.4314/ijbcs.v6i4.20

Djadji, E. L. G., Konan, K. J., Sylla, S., \& Atse, B. C. (2013). Identification simplifiée des Mugilidae. Fiche Technique et Document de Vulgarisation, 13-18.

FAO. (2016). Report of the FAO Working Group on the Assessment of Small Pelagic Fish of Northwest Africa. Banjul, the Gambia, 18-22 may 2010. Rome: FAO.

Fernandez, W. S., \& Dias J. F. (2013). Aspects de la reproduction de Mugil curema (Valenciennes, 1836) dans deux systèmes côtiers du Sud-Est du Brésil. Tropical Zoology, 26(1), 15-32. https://doi.org/10.1080/03946975.2013.775052

Fréon, P. (1988). Réponses et adaptations des stocks de clupéidés d'Afrique de l'ouest à la variabilité du milieu et de l'exploitation: Analyse et réflexion à partir de l'exemple du Sénégal. Collection Etudes et Thèses, ORSTOM.

Ibañez-Aguire, A. L., \& Gallardo-Cabello, M. (2004). Reproduction de Mugil cephalus et M. curema (Poissons: Mugilidae) d'un lagon côtier du golfe du Mexique. Bulletin of Marine Science, 75, 37-49.

Ibañez-Aguire, A. L. (1993). Coexistence de Mugil cephalus et Mugil curema dans une lagune côtière $\mathrm{du}$ golfe $\mathrm{du}$ Mexique. Marine Biology, 42, 959-961. https://doi.org/10.1111/j.1095-8649.1993.tb00401.x

Jacot, A. P. (1920). Caractères d'âge, de croissance et d'échelle des mullets, Mugil cephalus et Mugil curema. Transactions de l'American Microscopial Society, 39, 199-229. https://doi.org/10.2307/3221748

Kébé, M. (1994). Etude des systèmes de production et de commercialisation dans le secteur des pêches au Sine-Saloum. Dakar: CRODT.

King, M. G. (1996). Fisheries Biology, Assessment and Management. Fishing News Book, Oxford, UK. 341 p. 


\section{Macrothink

Laloë, F., \& Samba, A. (1990). La pêche artisanale au Sénégal: Ressources et stratégies de pêche. Collection Etud. Thèses. ORSTOM.

Marin, E., Quintero, B. J. A., Bussire, D., \& Dodson, J. J. (2003). Reproduction et recrutement du mulet blanc (Mugil curema) dans une lagune tropicale (île de Margarita, Venezuela) révélée par la microstructure des otolithes. Bulletin des pêches, 101, 809-821.

Pal, M., Samal, N. R., Roy, P. K., \& Roy, M. B. (2014). Temperature and dissolved oxygen stratification in the Lake Rudrasagar Preliminary investigations. Sustainability, Agri, Food and Environmental Research, 2(1), 1-12. https://doi.org/10.7770/safer-V2N1-art765

Pauly, D. P. (1997). Méthodes pour l'évaluation des ressources halieutiques. Adaptation française Moreau J. Cepadues, Paris. 288 p.

Salomon, F. N., \& Ramnarine, I. W. (2007). Biologie de la reproduction du mulet blanc, Mugil curema (Valenciennes) dans les Caraïbes du Sud. Recherche Halieutique, 88(1-3), 133-138. https://doi.org/10.1016/j.fishres.2007.06.024

Salvador, R. R. (2017). Aspects reproductifs de Mugil curema (Mugiliformes: Mugilidae) dans le lagon côtier de Barra de Navidad, Jalisco, Mexique. Revue Latino-Américaine de Recherche Aquatique, 45(2), 443-456. https://doi.org/10.3856/vol45-issue2-fulltext-19

Seiyaboh, E. I., Harry, G. A., \& Izah, S. C. (2016). Length-Weight Relationship and Condition Factor of Five Species from River Brass, Niger Delta. Biotechnological Research, 2(4), 187-192.

Sylla, S., Atsé, B. C., \& Kouassi, N. J. (2009). Stratégie de reproduction du Carangidae Trachinotus teraia Cuvier, 1832 dans la lagune Ebrié (Côte d'Ivoire). Sciences Naturelles, 6(1), 83-94. https://doi.org/10.4314/scinat.v6i1.48662

Vall, O. M. (2004). Etude de la dynamique des systèmes d'exploitation et de l'écobiologie de la reproduction de trois Mugilidae: Mugil cephalus (Linnaeus, 1758), Liza aurata (Perugia, 1892) et Mugil capurrii (Risso, 1810). Analyse de leurs stratégies d'occupations des secteurs littoraux mauritaniens et de leurs possibilités d'aménagement. Thèse Doct., Univ. Nice-Sophia Antipolis, France, 146 p.

\section{Copyright Disclaimer}

Copyright for this article is retained by the author(s), with first publication rights granted to the journal.

This is an open-access article distributed under the terms and conditions of the Creative Commons Attribution license (http://creativecommons.org/licenses/by/4.0/). 